\title{
LOGICAL AND SEMANTICAL ASPECTS OF THE PROBLEM OF EVIL*
}

\author{
EDUARDO O. C. CHAVES
}

UNICAMP

"And is it possible, Cleanthes, said Philo, that after all these reflections, and infinitely more, which might be suggested, you can still persevere in your anthropomorphism, and assert the moral attributes of the Deity, his justice, benevolence, mercy, and rectitude, to be of the same nature with these virtues in human creatures? His power we allow infinite: Whatever he wills is executed: But neither man nor any other animal are happy: Therefore he does not will their happiness. His wisdom is infinite: $\mathrm{He}$ is never mistaken in choosing the means to any end: But the course of nature tends not to human or animal felicity: Therefore it is not established for that purpose. Through the whole compass of human knowledge, there are no inferences more certain and infallible than these. In what respect, then, do his benevolence and mercy resemble the benevolence and mercy of men?"

"Epicurus's old questions are yet unanswered. Is he willing to prevent evil, but not able? then he is impotent. Is he able, but not willing? then he is malevolent. Is he both able and willing? whence then is evil?" (Philo)

"For to what purpose establish the natural attributes of the Deity, while the moral are still doubtful and uncertain?" (Cleanthes)

David Hume, Dialogues Concerning Natural Religion, ch. X.

Are the statements that there is evil in the world and that there exists a God who is omnipotent, omniscient, and per-

* Este trabajo fue presentado como ponencia el 17 de diciembre de 1976 en las jornadas "Adam Smith, David Hume y su época", organizadas en Buenos Aires por el Instituto Torcuato Di Telle, con la colaboración de la Sociedad Argentina de Análisis Filosófico, el Centro de Investigaciones Filosó. ficas y la Asociación Argentina de Economía Política. 
fectly good logically inconsistent or incompatible? The question is, at least, as old as Sextus Empiricus, ", and David Hume gave it a classical treatment. ${ }^{2}$ However, there has been considerable discussion of this question lately, and an apparent emerging consensus seems to be that although many have answered this question in the affirmative it is highly debatable whether they have established their position - or, even further, whether their position is capable of being established at all. ${ }^{3}$ Those who claim that no contradiction has been proved to exist between the two statements appeal to a variety of considerations to justify their conclusion. The purpose of this paper is to clarify some of the issues involved in the problem and to place some of the more recent discus. sions of this question in some sort of synoptic perspective. In so far as possible it will not be my intention to take issue with either side in the dispute, except to point out and clarify some of their presuppositions and assumptions. If I were asked to put forth a thesis concerning this issue, I would merely say that in it semantical equivocation prevents the settlement of its logical aspects. ${ }^{4}$

1 Cf. Sextus Empiricus, Outlines of Pyrrhonism, translated by R. G. Bury (London, 1933), vol. I, pp. 330-333.

2 David Hume, Dialogues Concerning Natural Religion, edited, with an Introduction, by Norman Kemp Smith (New York, 1947; originally published in 1935), chs. X and XI. I have discussed Hume's treatment of the problem at great length in ch. VII of my David Hume's Philosophical Critique of Theology and its Significance for the History of Christian Thought (Ph. D. Dissertation, University of Pittsburgh, 1972).

3 Nelson Pike, on the other hand, was very firmly convinced that there was no incompatibility between the two statements at one time. More recently he seems to have lost some of his confidence. If I am allowed to interpret some of his interesting autobiographical remarks concerning his views on the matter, he seems to have thought that it was "obviously wrong" to suppose that there was a contradiction between the two statements in question; then he changed his mind and argued "that at least it has not been shown (nor is it easy to see how could be shown)" that there was a contradiction in the case; under criticism, he then admitted that his "confidence in this latter position has since been shaken (though not destroyed)". Cf. the Commentary to his edition of David Hume's Dialogues Concerning Natural Religion (Indianapolis, New York, 1970), p. 193, n. It must be stated that Pike's remarks were made in a slightly different context: see below, footnote 26 .

4 I will not be concerned with Humean exegesis in this paper; this I have done in the work mentioned in footnote 2 . As the reader will promptly realize, 
One thing is clear and should be stated right at the outset: if there is logical inconsistency in holding the two statements referred to at the beginning, this inconsistency is not obvius or apparent. Something more will have to be added before the inconsistency becomes evident. ${ }^{5}$ Henry David Aiken, whose interesting article in Ethics (1958) seems to have brought Nelson Pike to the public arena of discussion of the problem of evil, poses the question in the following way:

"As here undestood, the problem of evil tends to arise whenever there is a disposition on the part of anyone to assent to both of the following propositions: (a) there is an almighty and omniscient being who is perfectly good and who alone is God; and (b) there is something in the finite universe created by that being which is evil."

Aiken claims that there is an "inconsistency" between these two propositions, and so he qualifies as one of those who have answered our original question in the affirmative.

however, most of the issues dealt with in this paper were raised by Hume, who was very much interested in both the logical and the semantical aspects of the problem of evil. As the quotation placed at the beginning of this paper shows, he is concerned with showing, through Philo, that if God's "benevol. ence and mercy resemble the benevolence and mercy of men" the incompatibility between the two statements mentioned at the beginning is quite obvious. If God's benevolence and mercy are understood, however, in an entirely different sens, the problem of the incompability is minimized, but others arise, such as the problem of the meaning of God-language. Hume also correctly emphasized, this time through Cleanthes, that the crucial aspect of the problem of evil is related to the moral attributes of the Deity, not to his natural attributes (omnipotence and omniscience, for example), for there is not much sense in trying to establish the natural attributes of the Deity "while the moral are still doubtful and uncertain". The article which is discussed through most of this paper deals with Hume's views on the question of evil: Nelson Pike's "Hume on Evil", The Philosophical Review, LXXII (reprinted in Nelson Pike, ed. God and Evil, Englewood Cliffs, 1974).

- Cf. Alvin Plantinga, God and Other Minds (Ithaca, London, 1967), pp. 116-117. Cf. also John Wisdom, "God and Evil", Mind, XLIV, p. 5.

"6 Henry David Aiken, "God and Evil: A Study of Some Relations between Faith and Morals", Ethics, LXVIII, p. 79. Nelson Pike's reply, "God and Evil: A Reconsideration", appeared in the same issue, pp. 116-124. 
But he knows that the inconsistency is not plainly visible, and therefore he tries to show where it can be found:

"Their inconsistency [i.e., the inconsistency between (a) and (b)] may be seen in the following way: By hypothesis, an almighty and omniscient being can do whatever it wills. But any perfectly good person, so far as he can, will do good and prevent evil. On the other hand, if something is evil, it must be concluded that there is no such being, since a perfectly good person would prevent it if he could, and an almighty and omniscient being could prevent it if it would. Either, then, there is no such being or nothing is evil. But since, by hypothesis, only such a being is God. we are forced to conclude either there is no God or else that there is nothing which is evil."

I must confess that I have some difficulty understanding what Aiken means by the expression "by hypothesis" in this passage. It seems to me that it could be interpreted as meaning merely "by definition". By referring to it as a hypothesis, Aiken may have meant this definition is proposed by theists in a hypothetical way and they will want to retain this definition as long as they can (i.e., they will not want to "solve" the problem by redefining omnipotence, or omniscience, or goodness, or God). Since I find no other interpretation of the expression plausible, I will assume that this is what Aiken meant.

Before we go on to examine the claims made by Aiken as to the meanings of the terms involved in the discussion, let us stop for a minute and discuss the reasons why Aiken formulated his statement (a) the way he did. He calls (a) the theological thesis and (b) the ethical thesis. The theological thesis, however, includes three components or claims: a metaphys-

7 Aiken, p. 79. 
ical, a moral, and a religious one. The metaphysical component is the claim that there is a being who is omnipotent and omniscient. Omnipotence and omniscience were usually referred to as metaphysical or natural attributes of God. The moral component is the claim that there is a being who is a perfectly good person. Goodness is a moral, rather than a methaphysical or natural, attribute of God. The religious component of the theological thesis is the claim that only a being who is omnipotent, omniscient, and perfectly good is God. The importance of making these distinctions is to be seen in the fact that the theist can "solve" (or, better, evade) the problem by rejecting either the metaphysical or the moral claim. Of course, he can reject both: the important thing, however, is that he does not have to. But in order to reject either the metaphysical or the moral claim, and still remain a theist, he must reject the religious claim first. That is, he must redefine God: he must be willing to claim that a being who is either not-omnipotent and/or notomniscient or not perfectly good can still be appropriately called God. That this move, however, does not offer a solution for the problem of evil as it was originally formulated is obvious. Our question was whether the statement that there exists a God who is omnipotent, omniscient, and perfectly good is incompatible with the statement that affirms the exis. tence of evil in the world. Although those who decide to evade the problem in the way just outlined may have implicitly (or even explicitly) answered our original question in the affirmative -otherwise, why would they want to change the terms of the problem? - the reasons why they may have done so constitute our main inquiriy now. ${ }^{8}$

8 Of course another "solution" of the problem is even simpler: one can endorse the theological thesis without limitations but claim that God possesses these attributes in an entirely different (and mysterious) sense, which is incomprehensible. Demea and Philo, in Hume's Dialogues, take this approach, for different reasons. The approach is vehemently criticized by John Stuart Mill. See, for instance, the selection "Mr. Mansel on the Limits of Religious Thought", reprinted in God and Evil, ed. by Nelson Pike, pp. 37-45. In Hume's Dialogues Cleanthes prefers the option of admitting that God is only "finitely perfect", not infinitely so. 
Going back to our main inquiry, Aiken claims that the inconsistency will only be seen if we realize that "an almighty and omniscient being can do whatever it wills" and that "any perfectly good person, so far as he can, will do good and prevent evil". It is clear that one will only be convinced that there is an inconsistency between the theological and the ethical theses if he is willing to accept these sub-premises. The two sub-premises make explicit the meanings (or part of the meanings) of the key terms involved in the argument. The first one specifies the meaning of omnipotence and omniscience, and the second one specifies the meaning of goodness, when applied to persons. ${ }^{{ }^{\circ}}$ It seems clear that if these sub-premises are accepted the inconsistency between what Aiken calls the theological and the ethical theses is obviously real..$^{10}$ The problem, now, is to investigate whether these sub-premises are at all acceptable to the theist (i.e., to the uncompromising theist), and, if they are not, to see why.

\section{II}

As far as I can see, no theist would object to the first of the two sub-premises mentioned above - "an almighty and omniscient being can do whatever it wills"- provided the qualification is made that whatever he is supposed to do is

๑ J. L. Mackie, in his celebrated article, "Evil and Omnipotence", Mind, LXIV, reprinted in God and Evil, ed. by Nelson Pike, observes that "the contradiction does not arise immediately; to show it we need some additional premises, or perhaps some quasi-logical rules connecting the terms 'good', 'evil', and 'omnipotent'. These additional principles are that good is opposed to evil, in such a way that a good thing eliminates evil as far as it can, and that there are no limits to what an omnipotent thing can do. From these it follows that a good omnipotent thing eliminates evil completely, and then the propositions that a good omnipotent thing exists, and that evil exists, are incompatible"; p. 47 of God and Evil.

10 The reason why Keith Yandell does not seem to see the clear contradiction which results once these sub-premises are added is that instead of adding a sub-premise to the effect that a perfectly good being will always prevent evil, if he can, he merely states the logical truth that a perfectly good being will always do good, if he can (Basic Issues in the Philosophy of Religion, Boston, 1971, p. 46). By doing so he is then able to claim that even a perfectly good being can cause or allow evil without ceasing being good, something Aiken and Mackie would deny. 
not logically impossible. As a matter of fact, the claim that God (as an omnipotent being) can do whatsoever that is logically possible has been orthodox Christian teaching for centuries. Thomas Aquinas, for instante, answering the question "Is God Omnipotent?", says:

"By common profession God is almighty. Yet it seems hard to lay one's finger on the reason, because of the doubt about what is meant by 'all' when you say that God can do all. Yet looked at aright, when you say God has the power for everything, you are most correctly interpreted as meaning this: that since power is relative to what is possible, divine power can do everthing that is possible, and on this account is God called omnipotent."

"Whatever does not involve a contradiction is in that realm of the possible with respect to which God is called omnipotent. Whatever involves a contradiction is not held by omnipotence, for it just cannot possibly make sense of being possible. Better, however, to say that it cannot be done, rather than God cannot do it."

Although there have been those who have claimed that God can do even the logically impossible, since logic is also his creation, this opinion has not carried the theological scene. So, provided this qualification is made, most theists would accept the claim that an omnipotent and omniscient being can do anything whatsoever.

The other sub-premise, however, has not faced equal luck. Nelson Pike, for example, has been a champion of the cause that it is simply not true to say that a perfectly good person would prevent evil, if he could. In his article "Hume on Evil" he says: "I do not think it follows from the claim that a being

m Thomas Aquinas, Summa Theologiae, translated and edited by Thomas Gilby, O. P. (Garden City, 1969), I, Q. 26, a. 3, c.a. 
is perfectly good that he would prevent evil if he could". ${ }^{12}$ In his reply to Aiken he claims that "a perfectly good person could allow evil, or for that matter be himself an evildoer", provided only that there is what Pike is going to call a "morally sufficient reason" for his doing so. ${ }^{13}$ Pike observes that the point is "strictly semantical". ${ }^{14}$ The sub-premises we are dealing with were introduced in order to specify the meaning of the key terms involved in the discussion. Pike's point is that we ordinarily do not refrain from calling someone good (or even perfectly good, for that matter) merely because he either allowed or caused some evil, provided he had a "morally sufficient reason" for so doing. Pike illustrates:

"Consider this case. A parent forces a child to take a spoonful of bitter medicine. The parent thus bring about an instance of discomfort - suffering. The parent could have refrained from administering the medicine; and he knew that the child would suffer discomfort if he did administer it. Yet, when we are assured that the parent acted in the interest of the child's health and happiness, the fact that he knowingly caused discomfort is not sufficient to remove the parent from the class of perfectly good beings. If the parent fails to fit into this class, it is not because he caused this instance of suffering."16

The semantical point can be granted, provided a small qualification is made: one would only say that the father had a morally sufficient reason for causing suffering in this case if the bitter medicine were the only means known to the

12 Loc. cit., p. 182. Cf. Plantinga, p. 118.

13 "God and Evil: A Reconsideration", p. 119. The expression "morally sufficient reason" first appears in "Hume and Evil", not in the previous article in Ethics.

14 Ibid., ibid.

15 "Hume on Evil", p. 183. 
father for bringing about the desired end, namely, the child's health. ${ }^{16}$ Were other means known to him which did not involve any discomfort to the child, other things being equal, we would not consider the father good for having chosen the one that involved more suffering to the child. ${ }^{17}$

Also with respect to this argument presented by Pike, T.P.M. Solon and S.K. Wertz have claimed that "presumably, however, an almighty parent could have made the medicine sweet and/or prevented the illness altogether". ${ }^{18}$ This seems to be true enough. However, at this stage, it does not affect Pike's argument, for his point, as he observed, was "strictly semantical": ordinarily we do not refrain from calling someone good because he either allowed or caused evil, provided he had a morally sufficient reason for doing so. And this point can be granted to him, for we ordinarily do not deal with omnipotent and omniscient beings.

Pike, however, does not define the expression "morally sufficient reason" very precisely. He merely says:

"To say that there is a morally sufficient reason for his [i.e., the parent's] action is simply to say that there is a circumstance or condition which, when known, renders blame (though, of course, not responsibility) for the action inappropriate."

We may have to render this notion more precise as we go on. However, for the moment the important thing is that Pike now claims, on the basis of this consideration, no longer simply that it does not follow "from the claim that a being is perfectly good that he would prevent suffering if he could", but also that "it does not follow from the claim that God is

16 And also if the desired end - the child's health - were more valuable than the absence of discomfort occasioned by the non-administration of the bitter medicine.

a7 One can easily imagine a situation in which a sadistic father, while desiring his child's health, seeks only painful means of achieving this end.

is T. P. M. Solon and S. K. Wertz, "Hume's Argument from Evil", The Personalist, L, pp. 389-390.

19 "Hume on Evil", p. 183. 
perfectly good that he would prevent suffering if he could", ${ }^{20}$ The reason for this new claim is not difficult to imagine: "God might fail to prevent suffering, or himself bring about suffering, while remaining perfectly good. It is required only that there be a morally sufficient reason for his action."21

It seems clear that whatever may be, the merits of the claim Pike is now making, it is not identical with the claim he had made a few paragraphs before, nor does it follow from the previous one. The point I am making here is "strictly logical". The reason for this non sequitur ir not far to seek: God, in addition to being perfectly good, according to traditional theism, is also said to be omnipotent and omniscient, and these natural attributes ascribed to him seem to rule out any morally sufficient reason which he migth possibly have. ${ }^{22}$ After all, this is what lies underneath the problem of evil, namely, the fact that God's "metaphysical attributes" seem to foreclose any possibility of justifying him for the existence of evil. As Antony Flew observed in his reply to the commentators on his "Theology and Falsification", God seems to have been endowed with attributes "which rule out all possible saving explanations". ${ }^{23}$ It seems to me then that Pike would have to analyze the expression "morally sufficient reason" very carefully, to see if it does not necessarily involve a reference to lack of power or knowledge, before he can claim that it is capable of being applied to God. ${ }^{24}$ This he does not

20 Ibid., ibid.

21 Ibid., ibid

22 At this point the remark made by Solon and Wertz is indeed appropriate.

23 Antony Flew, "Theology and Falsification", in New Essays in Philo. sophical Theology, edited by Antony Flew and Alasdair MacIntyre (London, $1955)$, p. 107.

24 Donald F. Henze, in his "On Some Alleged Humean Insights and Oversights" (Religious Studies. VI, pp. 370-372), argues that it is meaningless to apply the notion of a morally sufficient reason to what he calls an "omnibeing". His reason for claiming this, however, is strange: "There is no clear sense", he remarks, "in which omni-beings or perfect beings can be thought of as moral agents" (p. 372). If this is so, the problem of evil seems hardly to arise, for if God is not a moral agent, he certainly cannot be blamed for allowing evil. Dewey Hoitenga, in his "Logic and the Problem of Evil" (American Philosophical Quarterly, IV) also points out important features of the notion of morally sufficient reason which may make it inapplicable to God. 
do at all in his 1958 article in reply to Aiken. There he merely shows, by means of similar considerations, that it is false "that a perfectly good person would of necessity prevent evil if he could", and then concludes, in his very next statement:

"If then it is not contradictory to admit God [N.B!] as an omniscient, omnipotent, and perfectly good person and still admit that he either could not or would not prevent evil in the world, it is clear that the theological and ethical theses do not contradict one another in any formal way. ... These conclusions are strictly formal and require only an examination of the logical or semantical aspects of the issue." 25

Now, one of the logical or semantical aspects of the issue is whether the notion of a morally sufficient reason, which admittedly does have a place among finite beings - but per. haps only because of their finitude- can at all be applied to an omnipotent and omniscient being. Pike in 1958 simply took for granted that it did."

In his 1963 article Pike shows more awareness of some of the difficulties involved in this question. For instance, after examining several morally sufficient reasons that have been suggested to explain why God would allow evil, and granting the possibility that not even one of them was successful, he makes the very perceptive and promising remark:

"Might there not be a principle operating in each of these reasons which guarantees that no morally

25 "God and Evil: A Reconsideration", pp. 119-120.

20 Perhaps this is why he thought, at the time he wrote the article in Ethics, that "Philo was obviously wrong in supposing that there could be no morally sufficient reason for evil in a universe created by an omnipotent and om. niscient being" (Commentary on Hume's Dialogues, p. 193, $\mathrm{n}$; the Philo he refers to is the main figure of Hume's work). This is the context in which the observations mentioned in footnote 1 are found. 
sufficient reason for permitting suffering could be assigned to an omnipotent and omniscient being? Such a principle inmediately suggests itsely [although, apparently, not to the 1958 Pike]. Men are sometimes excused for allowing suffering. But in these cases, men are excused only because they lack the knowledge or power to prevent suffering, or because they lack the knowledge or power to bring about goods (which are causally related to suffering) without also bringing about suffering. In other words, men are excusable only because they are limited. Having a morally sufficient reason for permitting suffering entails having some lack of knowledge or power."

However, although Pike observes that this possibility "immediately suggests itself" and that it is "initially plausible", he throws the burden of proof onto the skeptic's lap! It is the skeptic, he claims, that has to show that no morally sufficient reason can apply to an omnipotent and omniscient being. And the requirement is that he must show this to be not only true, but also necessarily true - presumably because unless the skeptic shows this to be necessarily true there will be no formal contradiction between the theological and the ethical theses (being always possible, I presume, that the theist might claim that a contingent truth is only probable and therefore might be false). It is this statement, that no morally sufficient reason can apply to an omnipotent and omniscient being, that Pike contends no one has yet shown to be true, let alone necessarily true, and concerning which he wonders how it could be shown.

27 "Hume on Evil", p. 188.

Ibid., p. 183.

29 Cf. Keith Yandell, "A Premature Farewell to Theism", in Religious Studies, V, p. 251, n. 1 . 
However, I have not been entirely fair to Pike in claiming that he threw the burden of proof onto the skeptic's lap, because he does offer an argument to show that, and how, even an omnipotent and omniscient being might have a morally sufficient reason for allowing evil. (Pike is not interested in showing that God did in fact have a morally sufficient reason for allowing evil. He is content with trying to show that God might have had such a reason, for if he does this he will have shown that the skeptic cannot show that the statement that no morally sufficient reason can apply to an omnipotent and omniscient being is necessarily true.) Thus, at the same time that Pike throws the burden of proof onto the skeptic's lap, he gives the skeptic a reminder that his task is hopeless. Although this seems to take some of the pressure off the skeptic's shoulders, Pike in fact is not giving out any grounds, for even if his argument fails he can still say that its failure does not prove that his opponent's claim is necessarily true. If the skeptic wants his argument to be forceful, he will have to argue for it.

Pike's argument, however, has considerable merits because it brings to the surface several other issues which will help us to clarify the logical and semantical aspects of the problem of evil a little bit more. Let us then investigate it. His argument has the following lay-out:

(a) An ommipotent, omniscient, and perfectly good being would create the best of all possible worlds;

b) It is logically possible - or, at least, it cannot be shown to be logically impossible - that the best of all possible worlds might contain instances of suffering;

(c) If it is logically possible that the best of all possible worlds might contain instances of suffering, these instances of suffering would be logically necessary components of the best of all possible worlds;

(d) "Thus, if it is possible that instances of suffering are necessary components of the best of all possible worlds, then 
there might be a morally sufficient reason for an omnipotent and omniscient being to permit instances of suffering". ${ }^{30}$

The crucial premise in this argument is, of course, $(b)$. Is it logically possible that there might exist evil in the best of all possible worlds? If this is in fact possible - something that most skeptics will be inclined to deny- then it follows (granting $(c)$, for the sake of the argument) that it might be logically impossible for an omnipotent and omniscient being to create a world without evil in it, provided only that this being should choose to create the best of all possible worlds - something he would do, according to Pike, if he were also perfectly good. In this case an omnipotent, omniscient, and perfectly good being (God) might possibly have a morally sufficient reason for allowing evil to exist.

Pike considers this argument to be enough to show that an omnipotent and omniscient being might have a morally sufficient reason for allowing evil to exist, and therefore enough to show that the skeptic cannot possibly show that the statement "there can be no morally sufficient reason for an omnipotent and omniscient being" is necessarily true.

Before we analyze in more detail the argument offered by Pike, let us see, briefly, what exactly Pike showed, when all of the premises and inferences of his argument are granted.

In the first place, the argument shows, if sound, that it would be logically impossible for an omnipotent, omniscient, and perfectly good being to create an evil-free world. This fact would then constitute a morally sufficient reason for not blaming this being. Pike's argument indirectly suggests that any morally sufficient reason that could possibly apply to an omnipotent and omniscient being would have to make the prevention of evil logically impossible, since it is only the logically impossible that lies outside the capabilities of such being. Pike does not discuss this point as such, but it readily suggests itself.

\footnotetext{
so "Hume on Evil", p. 191. And, it might be added, this morally sufficient reason would not entail any lack of power or knowledge.
} 
Secondly, although Pike set out to prove that (and how) even an omnipotent and omniscient being (as such) might have a morally sufficient reason for allowing evil to exist, he has not really proved this, even if the premises and inferences of his argument are granted. At best he showed that there might be a morally sufficient reason for a being who is omnipotent, omniscient, and also perfectly good, since only a perfectly good being would be committed to creating the best of all possible worlds (of which, according to the argument, it is possible that evil might be a necessary component). So, given that an omnipotent and omniscient being would choose to create a world of which evil was a necessary component, it would be logically impossible for him to create an evil-free world. But this argument leaves the possibility open that this omnipotent and omniscient being might choose not to create a world of which evil were a necessary component -i.e., that he might not choose to create Pike's best of all possible worlds. In this case he might then be able to create an evil-free world!:a1

This certainly sounds paradoxical, and I will try to clarify the paradox below. The point to be made here is that even if Pike's assumptions are granted, his argument does not show that the skeptic's project of proving that there could be no morally sufficient reason for an omnipotent and omniscient being (as such) is necessarily doomed to failure. The possibility seems to have been left open for this being to create an evil-free world, provided only he would not choose to create the best of all possible worlds. In other words, the necessity of evil being a component of the world is not absolute: it is conditioned to this world being the best of all the possible worlds.

Pike could, of course, claim that we are being finicky

31 In a way it is too easy to find a reason why an omnipotent and omniscient being would create a world with evil in it. Suppose this being should choose to create the worst possible world -i.e., suppose he were also perfectly evil. Given then the kind of world he wanted to create, evil would be a logically necessary component of it. Although this being had a reason for creating and allowing evil, he did not have a morally sufficient reason. 
here, since the important question is whether God, who is perfectly good, in addition to being omnipotent and omniscient, might have a morally sufficient reason for allowing evil to exist. Let us, therefore, analyze in more detail his main premises.

Pike says: "God, being a perfectly good, omniscient, and omnipotent being, would create the best of all possible worlds".82 It is rather unclear what Pike means by this statement, for it can bear several interpretations. Does it mean that such a being would probably choose, as a contingent matter, to create such a world? Or does it mean that he would be bound to create it, as a matter of necessity? Or, further, should it be interpreted as meaning that such a being would not be bound to create anything at all, but that should he (as a contingent matter) decide to create anything he then would have (as a matter of necessity) to create the best? I think this third interpretation is the most plausible one, and consequently I will presume that this is what Pike meant. ${ }^{80}$ According to this interpretation, an omnipotent, omniscient and perfectly being might choose not to create anything at all, but, if he decides to create anything, he, being perfectly good, would have to create the best of all possible worlds. I presume most skeptics will agree with this, merely ex vi terminorum. I consequently conclude that premise $(a)$ of Pike's argument is not a matter of controversy. ${ }^{34}$

For the sake of the argument I will let premise $(c)$ of his argument remain unquestioned, not questioning also the inference from $(b)$ to $(c)$, in order to concentrate on $(b)$. It is here where Pike and his skeptical opponents will most certainly clash. Is it logically possible that evil might be a component of the best of all possible worlds?

The skeptic might begin by pointing out the rather para-

32 "Hume on Evil", p. 190.

${ }^{33}$ Cf. Terence Penelhum, Religion and Rationality (New York, 1971), pp. 225-226.

${ }^{34}$ It has been denied, though. Cf. Robert M. Adams, "Must God Create the Best?", Philosophical Review, LXXXI. 
doxical conclusion, mentioned above, which seems to be derivable from Pike's argument, namely, that an omnipotent and omniscient being, not committed to create the best of all possible worlds, might possibly create an evil-free world, whereas the same being, committed to the creation of the best of all possible worlds, might have to create a world containing evil. In other words, God's perfect goodness, which commits him to create the best, seems to prevent him, rather than the opposite, from creating an evil-free world. If this is so, the skeptic may wish to point out that God's goodness might at least have suggested to him the preferment of not creating anything at all, rather than something with evil in it. But this is not the point that the skeptic is liable to dwell upon. He might be much more interested in pointing out that the rather paradoxical conclusion reached above indicates that Pike is operating with a rather odd notion of "goodness".

Leaving aside (at least for the moment) the question as to whether Pike's notion of goodness is odd or not, it is clear that, odd or not, it is certainly different from the skeptic's notion of goodness. According to him, the notion of goodness is such that it involves a reference to the elimination or absence of evil. Aiken, as we saw above, claimed that "any perfectly good person, so far as he can, will do good and prevent evil". Mackie claimed that "good is opposed to evil, in such a way that a good thing eliminates evil as far as it can". Goodness is here understood as being radically opposed to evil, so that of two possible worlds, one being evil-free, the other containing evil, there is no question that the first one should be judged the better one, not the second. The skeptic would agree that a perfectly good being would have to choose the best, but would argue that the best of all possible worlds would be an evil-free world, pointing out that it would be possible -or at least Pike did not show it to be impossible- for an omnipotent and omniscient being to create this world, if he only would.

According to Pike's notion of goodness, goodness is not 
radically opposed to evil, for evil may even be a necessary ingredient in the best (i.e., "most good") of all possible worlds. In other words, a possible world might not be the best, unless there were evil in it. ${ }^{35}$ Dewey Hoitenga summarises very well, I believe, the differences between the two notions of goodness:

"For the sceptic a state of affairs can be good, or a higher good, only if it is without evil. Introduce whatever so small amount of evil possible into this state of affairs, and it becomes less than good, less than a state of affairs containing no evil whatsoever ... For the theist, however, the introduction of evil into a good state of affairs need not lessen the goodness of the whole; indeed, he holds that such an introduction can occur leaving the whole better than it was".

Pike's notion of goodness and his conclusions, are not, of course, novel. Leibniz, for one, argued for something virtually identical. In his abridgment of the argument of the Theodicy, he has his fictitious opponent proving his claim that "God did not choose the best in creating this world" by means of the following argument:

"Whoever makes things in which there is evil, which could have been made without any evil, or the making of which could have been omitted, does not choose the best. God has made a world in which there is evil; a world, I say, which could have been made without any evil, or the making of which could have been omitted altogether. Therefore God has not chosen the best".

35 In this context the articles by Mackie and Hoitenga are quite interesting.

36 Hoitenga, pp. 117 ff. Cf. also Penelhum, pp. 234, 239. 
In his reply to this argument Leibniz grants the minor premise:

"For it must be confessed that there is evil in the world which God has made, and that it was possible to make a world without evil, or even not to create a world at all, for its creation depended on the free will of God".

However, he denies the major, thereby showing that he has a concept of goodness virtually identical to Pike's:

"I deny the major... and I might content myself with simply demanding its proof; but in order to make the matter clearer, I have wished to justify its denial by showing that the best plan is not always that which seeks to avoid evil, since it may happen that the evil will be accompanied by a greater good". 37

Where does this leave us? Pike claimed to have show that there might be a morally sufficient reason even for an omnipotent, omniscient and perfectly good being to allow the existence of evil in the world. The skeptic would probably reply to this by saying that:

(a) Pike did not show that there might be a morally sufficient reason for an omnipotent and omniscient being (as such) ;

(b) Pike showed that there might be a morally sufficient reason for an omnipotent, omniscient, and perfectly good being only with the help of a rather odd and untypical notion of goodness;

(c) Pike did not show, even with the help of his odd notion

37 G. W. Leibniz, "Abridgment of the Argument Reduced to Syllogistic Form", in The Philosophical Works of Leibniz, translated by George M. Duncan ( , 1890), pp. 194-195. 
of goodness, why this omnipotent, omniscient, and perfectly good being should decide to create anything;

(d) Pike did not show that this omnipotent, omniscient, and perfectly good being did in fact have a morally sufficient reason for allowing the existence of evil - grating his notion of goodness, he only showed that this being might have had a reason for allowing the existence of evil.

Let us elaborate a little on each of these issues.

\section{IV}

Pike and other theists would probably consider the first of these observations $(a)$ entirely innocuous and probably irrelevant. Their point, as already seen, is that the important thing is whether God might have a morally sufficiente reason for allowing evil, not whether an omnipotent and omniscient being (as such) might have it. Even admitting that the theist is correct when he observes this, however, we are going to discuss the issue in more detail, because its discussion will help us to clarify the notion of "morally sufficiente reason" a little more and will also throw some light on the assertion, made above, that apparently God can only be exempted from blame for the existence of evil in the world if its non-existence were logically impossible - since that is the only thing that lies outside the capabilities of an omnipotent and omniscient being.

There has not been much explicit discussion of the notion of morally sufficient reasons. I suggest, however, that the following analysis will cover most, if not all, of the cases in which it is employed. A morally sufficient reason would seem to involve either the non-prevention or non-removal of some evil, or the causing of some evil, in one of the following circumstances:

(i) The agent lacked knowledge or ability to prevent or remove the evil; 
(ii) The prevention or removal of the evil, or its nonoccurrence, would produce a greater evil $;^{38}$

(iii) The prevention or removal of the evil, or its nonoccurrence, would produce the removal or prevention of a greater good; $;$

(iv) The prevention or removal of evil would either be or involve a logical impossibility.

Even a theist would agree that $(i)$ could not be applied to an omnipotent and omniscient being, and even a skeptic would grant that ( $i v$ ) could. The skeptic, of course, would deny that the prevention or removal of evil would be or involve a logical impossibility - but about this more will be said below. Let us, for the moment, concentrate our attention (ii) and (iii). Concerning them the skeptic would probably remark that if the relation between the removal or prevention of the evil and the occurrence of a greater evil, on the one hand, or the non-occurrence of a greater good, on the other, is merely a causal one, then (ii) and (iii) could not provide a morally sufficient reason for an omnipotent and omniscient being, for this being is not limited by causal laws. ${ }^{40}$ This being could devise alternative means of accomplishing the same ends. If this relation is a logical one, however, in the sense that it would be logically impossible for those ends to be achieved except by causing or allowing evil, then the skeptic may have two courses of action: he may argue either that an omnipotent and omniscient being could conceivably devise alternative ends which did not logically require the undesirable means, or, if this is judged far-fetched and absurd, that an omnipotent and omniscient being, who was also perfectly good, should give up these ends, and, with them, the undesirable means. But arguing in this second manner, the skeptic is introducing again his own notion of goodness, which is admittedly rejected by the theist.

38 Cf. "Z" in Yandell, Basic Issues, p. 47.

39 Cf. "Y" in Ibid., ibid. Cf. also Plantinga, p. 118.

40 Cf. Yandell, Basic Issues, p. 48; Penelhum, pp. 224-225, 230-233. 
In any case, however, even if these two arguments of the skeptic are rejected by the theist, it can still be pointed out that when (ii) and (iii) are interpreted in a logical rather than in a causal sense they are reduced to (iv). In other words, if the relation between the removal or prevention of evil and the occurrence of a greater evil or the non-occurrence of a greater good is such that it would be logically impossible for these ends to be achieved except through the use of means which involve evil, then the removal or prevention of this evil would involve a logical given impossibility, of course, that the ends are chosen.

So, the suspicion alluded above to the effect that probably the only kind of morally sufficient reason which could possibly apply to an omnipotent and omniscient being is one that will make the prevention or removal of evil logically impossible seems to be confirmed, since it is only the realm of the logically impossible that lies outside the capabilities of this being. ${ }^{41}$

But what about $(i v)$ ? The skeptic contends that the prevention or removal of evil is not a logical impossibility, and therefore claims that an omnipotent and omniscient being can prevent evil, if he chooses so. Several theists, including Leibniz, agree with this - "it must be confessed... that it was possible to make a world without evil", said Leibniz. They argue, however, that given the choice of certain ends the prevention of evil might be or involve the logically impossible. Most skeptics would agree with this assertion. If an omnipotent and omniscient being chose as his end to create the worst possible world, they would say, the prevention or removal of evil would be logically impossible, given this goal. The point at which theists and skeptics part company is reached when some theists claim that an omnipotent, omniscient and perfectly good being (God) would be committed, because of his goodness, to choose some ends which neces-

41 See above, p. 16. 
sarily (i.e., logically) involve the existence of evil. But this brings us to $(b)$.

\section{V}

Is Pike's (and the theist's) notion of goodness odd and untypical? This is a notoriously difficult question to settle, if indeed it can be settled at all. Appeal to dictionaries would certainly not settle it, nor would surveys of how ordinary people use the term. The paradigm-case argument would probably be judged unconvincing by both sides. ${ }^{42}$ The disagreement here should probably be considered irreconcilable, if by reconciliation one means that one side could possibly be convinced by the other.

One move that the skeptic might make would be to try to convince the theist of the fact that he holds a double standard of goodness, utilizing this notion of goodness only when he tries to justify God. Dewey Hoitenga has suggested that the notion of goodness utilized by the theist in this context was worked out just to cope with the problem of evil. ${ }^{43}$ In other context -when discussing God's inherent goodness, for example, in contradistinction to the goodness of what he created- theists seem to utilize a rather different notion of goodness - a notion which looks rather similar to that of the skeptic. Gustaf Aulén, for example, in a section entitled "The Christian Conception of God" of his book The Faith of the Christian Church, has a chapter with the heading "The Opposition of Love to Evil", in which he says:

"God's will stands in radical opposition to evil... Faith finds the deepest expression of the opposition of divine love to evil in the fact that in its struggle against evil this love does everything to overcome it, even going so far as to carry its burden and to

$\$ 2$ Cf., for example, the dispute between Plantinga and Flew over the paradigm use of "freedom". Hoitenga provides an interesting summary.

43 Hoitenga, pp. 118, 120, 124. 
sacrifice itself. The Cross stands, therefore, as the synthesis of love's radical opposition to evil and of its sovereignty over it". ${ }^{44}$

Not all theists, however, can be convicted of internal contradiction or of the utilization of double standards. In these cases, the notion of goodness which is utilized in the context of the problem of evil is probably the result of a hierarchy of values which is quite different from that adopted by the skeptic. The argument between them would then assume the form of a clash between value systems, and an assessment of this argument, besides being very difficult to reach, is beyond the scope of this paper. ${ }^{44 a}$

A discussion of $(c)$ will not take us much further, for basically the same issues will be involved there. We can presume that both the theist and the skeptic agree that God should create the best of all possible worlds. But the skeptic, assuming his own notion of goodness, claims that God should have created an evil-free world, or then nothing at all. The theist, on the other hand, holding a different notion of goodness, claims that a world with evil in it is not only better than nothing at all but even better than the evil-free world pro-

\footnotetext{
44 Gustaf Aulén, The Faith of the Christian Church. translated by Eric H. Wahlstrom and G. Everett Arden (Philadelphia, 1948), pp. 136-137.

44 a The differences, of course, are far from being merely verbal. The different meanings this key term has for both parties has to do with different value and ethical systems. For the theist morality is intrinsically valuable. The skeptic, on the other hand, often views morality from a functional point of view. Many theists are likely to say that a true moral character could not develop in a "hedonistic paradise" (Cf. John Hick, Evil and the God of Love, London, 1966; cf. also F. R. Tennat, Philosophical Theology, Cambridge, 1928). The best world, for these theists, is one in which true moral characters can evolve. The skeptic, on the other hand, tends to consider the so-called higher-order virtues (compassion, charity, etc.) as a means of producing pleasure and diminishing pain and suffering. If there existed a hedonistic paradise, in it there would be no need of such virtues - and the situation would be so much the better! Cf. in this context Penelhum, Mackie and also Wallace I. Matson, The Existence of God (Ithaca, 1965).
} 
posed by the skeptic. Why should God, then, have refrained from creating a world that is better than that proposed by the skeptic? Since we presumed that both agreed that God should create the best of all possible worlds, what could be the source of this disagreement if not two different conceptions of goodness, of what the best of all possible worlds would be like? The origin of the disagreement concerning the correct answer to the question posed at the beginning of this paper is to be found in these different notions of goodness. Most theists and skeptics agree on the logical aspects of the problem of evil. They disagree most severely, however, on this aspect, which is, in a certain way, semantical -although, of course, not merely semantical: the different notions of goodness may be the result of different value systems, and disagreements about values are not mere verbal disputes.

\section{VII}

The fact that God might have a morally sufficient reason for allowing the existence of evil, however, does not mean that he did in fact have one. The skeptic may argue that even if the theist's notion of goodness is granted the fact that evil might be a necessary component of the best of all possible worlds does not imply that ours is the best of all possible worlds, and that, as a result, evil is a necessary ingredient in it. As John Wisdom put it, in 1935,

"It remains to add that unless there are independent arguments in favour of this world's being the best logically possible world, it is probable that some of the evils in it are not logically necessary to a compensating good; it is probable because there are so many evils". ${ }^{45}$

This means that, as far as most skeptics are concerned, we have not yet reached the end of controversy. As a matter of

45 Loc. cit., p. 20). 
fact, some of them claim that the controversy is only beginning at this point, considering what was discussed so far uninteresting. ${ }^{46}$ Many opponents of theism are willing to concede the ground so far covered to the theist and still try to defeat him by showing that his suggested theodicies do not succeed.

For the development and articulation of a full-fledged theodicy three basic steps seem to be necessary:

(i) It has to be shown, in a manner similar to that chosen by Pike, that there might be a morally sufficient reason why God would allow evil to exist; in other words, it must be shown, in general, that the enterprise of building a theodicy is possible.

(ii) It has to be shown that the specific theodicy which is going to be proposed is possible; in other words: it must be shown that it fits under the morally sufficient reasons which have been seen to be applicable to God. (If we are correct in suggesting the only kind of morally sufficient reason that could possibly apply to God is one that would make the prevention of evil logically impossible, the basic task here will be to show that the specific theodicy which is proposed is such as to make the prevention of evil logically impossible.)

(iii) It has to be shown that the specific theodicy which is proposed was actually the reason why God allowed evil to exist in our world. ${ }^{47}$

Let us consider a famous example: the so-called "free will defense". Let us assume that what is described in (i) has already been done. The apologist will now have to show that the proposed theodicy is possible, in the sense that it fits under the kind of morally sufficient reason which can be applied to God. He will have to show that, given his notion of goodness, God would have to create free beings, since free

\footnotetext{
46f., for example, Edward H. Madden and Peter H. Hare, Evil and the Concept of God (Springfield, 1968).

47 In a theadicy involving the notion of the best of all possible worlds steps (i) and (ii) will probably be merged.
} 
will is, or is logically necessary for, ${ }^{48}$ a greater good. But he will have to show also that free will logically demands not only the possibility, but in fact the actuality of evil. ${ }^{49}$ In other word, he will have to show that it would be logically impossible for God to create a free person who would, nevertheless, always choose right and never choose evil. ${ }^{50}$

Now, skeptics can oppose the apologist at this level, and they have done so. They have been quick to point out this view will only get off the ground if libertarianism is true - point usually assumed by the apologists. ${ }^{51}$ Some skeptics then go on to argue that compatibilism is true instead, and that, consequently, it would not be self-contradictory - and therefore not logically impossible - for God to create free creatures who would nevertheless always freely choose to do the good and never the evil. ${ }^{62}$ We will not go into the details of this controversy (it has been quite well analyzed by Dewey

48 Cf. Terence Penelhum, "Divine Goodness and the Problem of Evil", Religious Studies, II.

49 If someone is free, does it follow that he will, sooner or later, necessarily choose evil? Thomas Aquinas argued that "what can fail sometimes does". See Hick, op. cit. Cf. also Matson, op. cit., p. 155. Hick presents a sophisticated attempt to show that the existence of evil is "virtually inescapable", given free will.

50 The free will defense seems to aim at justifying only moral evil. If this is so, other defenses will be needed for natural or physical evil. However, the suggestion is often made that some physical evil is necessary for the development of typically Christian virtues, which development, in its turn, logically presupposes free will. Cf. Penelhum, Religion and Rationality, pp. 237 ff., 240-24. C. also in this context G. Wallace, "The Problems of Moral and Physical Evil", Philosophy, 1971, pp. 34.9-351. Plantinga (pp. 149 ff.) attributes physical evil to Satan's free will.

$5 \cdot$ Many theists, however, were compatibilists, in order to allow for divine foreknowledge (or even predestination) to co-exist with human freedom. Cf. in this context Hoitenga's article.

52 Cf. Mackie's article and also Antony Flew, "Divine Omnipotence and Human Freedom", in New Essays, pp. 144-169, on the the skeptical side. Alvin Plantinga opposes their suggestions in his "The Free Will Defense", now incorporated in a revised form in his God and Other Minds. See Nelson Pike, "Plantinga on the Free Will Defense: A Reply", in The Journal of Philosophy (1966, pp. 93-104) and Plantinga's rejoinder: "Pike and Possible Persons" (Ibid, pp. 104-108). See also Clement Dore, "Plantinga on the Free Will Defense", The Review of Metaphysics (1971). Cf. also Antony Flew, "Compatibilism and the Free Will Defence", Philosophy (197). Ninian Smart has also replied to Mackie and Flew, and both have commented on his reply. See Smart's “Omnipotence, Evil and Supermen”, (Philosophy, XXXVI, 1961), 
Hoitenga)..$^{53}$ Let me just say that what is perhaps one of the most celebrated discussions of the free will argument in recent literature, Alvin Plantiga's "The Free Will Defense",.54 operates mostly at the level of trying to show that this theodicy is possible. $\mathrm{He}$ is not concerned with showing that the bestowal of free will on humans was indeed the reason why God allowed evil to exist. He is merely concerned with showing that the free will argument might provide a possible theodicy, since it would involve the claim that free will was a logically necessary condition for greater goods.

But even if the apologist succeeds here, the skeptic can still retort that the fact that free will is such a possible defense does not imply that it provides the actual reason why God would allow evil. The theist will only have a full-fledged theodicy if he show that was possibly the case was also actually the case..$^{55}$ The skeptic may grant all the points which have been made so far and still deny that the proposed theodicy does really present the reason why God allowed evil. ${ }^{56}$ Or he may at least challenge the theist to show how he knows that what was possibly on the case was also actually the case.

\section{VIII}

In closing, I would like to deal briefly with Pike's suggestion that the theist does not have to go at all past the first of the

Flew's "Are Ninian Smart's Temptations Irresistible?" (Ibid, XXXVII, 1962), followed by a halfpage rejoinder by Smart, "Probably" (in the same issue), and Mackie's "Theism and Utopia" (Ibid, ibid.)

58 Loc. cit.

54 The point is quite well made by Robert J. Richman, "The Argument from Evil", Religious Studies, IV.

${ }_{55}$ The theist sometimes forgets this. "Already believing in God, he thinks that if a certain possible arrangement of events would solve the problem of evil, then it is not probable but certain that God so arranged them"; Madden and Hare, op. cit. p. 65 .

50 At this stage of the game the apologist will have to explain concrete problems by showing how they fit into his theodicy, or how they are logically necessary to greater goods, etc. Even if he is arguing in the direction of a theodicy which involves the notion of the best of all possible worlds, he will have to show that ours is indeed the best of all possible worlds - and to do this he will have to show that every evil is logically necessitated by a greater 
three steps which we considered essential for the development of a full-fledged theodicy. In other words: Pike does not think that the theist has to present a full-fledged theodicy: he has only to show that a theodicy (in general) is possible. Here is Pike's argument. He sets up the problem of evil in the form of an inconsistent triad:

(a) There is evil in the world;

(b) There is a God who is omnipotent, omniscient, and perfectly good;

(c) There can be no morally sufficient reason why God would allow the existence of evil in the world (i.e., no theodicy is possible). ${ }^{67}$

These three propositions seem to be so related that any two of them can be consistently assented to as long as the third is denied. (a) is obviously true. The skeptic claims that $(c)$ is true and that, consequently, $(b)$ must be false. However, according to Pike, the skeptic is not (or at least has not been) able to show that $(c)$ is necessarily true, and therefore the theist is never compelled to consider $(c)$ as true. Now, Pike says, if the theist is assured, either through an a priori argument, or through revelation, that $(b)$ is true, then he can be sure that $(c)$ is false, on logical grounds alone; in other words, $(c)$ not only is, but must be false. In this case the theist can be certain of the fact that God not only might, but indeed must have a morally sufficient reason for allowing evil to exist. Pike then comments:

"What then of the traditional problem of evil? Within a theology of the above type [i.e., a theology that accepts the existence of God as an item of revelation or on the basis of an apriori argument], the problem of evil can only be the problem of discovering a specific theodicy which is ad-

good. One difficulty that often emerges at this stage is due to the fact that the theist often seems to have some private access to Godk purpose. The Christian can always retort, however, that some of God's purposes were revealed. Cf. Penelhum, Religion and Rationality, p. 225.

57 Pike, "Hume on Evil". This is not an exact quotation. 
equate - that is, of discovering which, if any, of the specific proposals which might be described really describes God's morally sufficient reason for allowing instances of suffering. This problem, of course, is not a major one for the theologian. If the problem of evil is simply the problem of uncovering the specific reason for evil - given the assurance that there is (and must be) some such reasonit can hardly be counted as a critical problem. Once it is granted that there is some specific reason for evil, there is a sense in which it is no longer vital to find it. A theologian of the type we are now considering might never arrive at a satisfactory theodicy. ... He might condemn as erroneous all existing theodicies and might despair of ever discovering the morally sufficient reason in question. A charge of incompleteness would be the worst that could be leveled at his world view".

Pike is also quick to point out that most of the theologians of importance in the history of Christian thought were theologians of the type just referred to: they took the existence of God to be "axiomatic".

So, according to Pike, the apologist needs only to occupy himself with the first of the three steps mentioned above. Let us investigate what the skeptic would say to this suggestion. Critics of this kind of argument usually begin by pointing out the fact that skeptic did not show that $(c)$ is necessarily true does not mean that it is not true. Even if it is contingently true, the theist will be faced with a contradiction in his beliefs - provided, of course, he accepts the statement as true, something he will not be forced to do, if it is merely contingently true. ${ }^{60}$

ss "Hume on Evil", pp. 193-194. Cf. also the Introduction to God and Evil.

59 Cf. "Hume on Evil", p. 197.

to Cf. Richman, loc. cit. Cf. also Yandell, "A Premature Farewell to Theism", p. 251, n. 1 . 
The skeptic may propose an example: let us consider the case of a small child dying slowly and painfully of hunger or disease. ${ }^{61}$ Could an omnipotent and omniscient being prevent that? He obviously could. But why does he not? Because some greater good may or will result, for which that specific evil is a logically necessary condition? It seems that the theist will have to take some such course. But unless he is able to explain what exactly this greater good is, and how it will result, the skeptic continues, the evil will have to be considered gratuitous - until, of course, shown to be otherwise. In other words, the skeptic will hold that there is a prima facie case for the blameability (and consequently for the absence of perfect goodness) of anyone who allows or causes evil. One who allows or causes evil will only be unblameable if he had a morally sufficient reason for doing what he did and is able to produce it. As Robert J. Richman put it, "if moral judgments are to make any sense at all, the burden of proof must be placed on the individual who has violated his prima facie duty - or on his defender- to supply the morally sufficient reasons for his doing so". ${ }^{82}$ The alternative is moral skepticism, for the following reasons:

"That an action is or involves the prevention of suffering is ipso facto a reason for performing the action. But an action (including here acts of omission) which is or involves a failure to prevent suffering is one which - so described - represents a reason against its performance, and one which requires the specification of a reason (e.g., ignorance of suffering caused, prevention of greater suffering, etc.) for its justification. ... It seems clear that it is wrong for a moral agent, ceteris paribus (i.e., in the absence of sufficient reasons to the contrary) to permit evil if he can prevent it. Indeed, it is wrong ceteris paribus for a moral agent to

61 Cf. Richman, p. 210.

22 Richman, pp. 208.209. 
permit evil, since inability to prevent evil normally counts as a sufficient excusing condition for not doing so. ${ }^{903}$

So, unless we are to succumb to total moral skepticism, those conditions that will defeat moral judgments which are prima facie correct must be specifiable, and it is not enough that there might be such conditions, for the mere possibility is not by itself sufficient ground for doubting their original acceptability.

But the point made by Pike was that in the case of God a theist of the type described will be certain that not only there might but there must be a morally sufficient reason why God allowed evil, since the existence of God $(b)$ is taken as "axiomatic". However, the skeptic will charge back by saying that although it is correct to say that theologian may go about at his usual business of theologizing taking the existence of God as axiomatic, the apologist cannot do so, for the whole point of the problem of evil, as skeptics conceive it, is to make the theologian doubt the reliability of his axioms! Considering a statement axiomatic does not make it true. ${ }^{6}$ Pike may admit this, but may retort that his theologian does not simply assume the truth of the statement in question: he claims to have evidence for its truth in the form of revelatory communications or of an a priori argument, and so he claims to "know" that God exists. At this point the skeptic will probably argue that the logic of the verb to "know" is such that

"to know, it is not enough to happen to be right, and to feel and act absolutely certain. You have

63 Richman, pp. 207, 208-209.

"64 Cf. Richman, p. 208. Cf. also Roland Puccetti, "The Loving God Some Observations on John Hick's Evil and the God of Love", Religious Studies, II, p. 267. This is the article to which Yandell replies in "A Premature Farewell to Theism". Hick himself replies to Puccetti in "God, Evil, and Mystery", Religious Studies, III, pp. 539-546.

65 Richman, p. 208. 
also to have reason sufficient to warrant that confidence. The upshot is that, until and unless such major objetions as the Problem of Evil are met, the existence of God cannot be taken as known. It remains possible that any ostensible proofs need to be re-examined or reassessed".

The point of the problem of evil is to make the theist question the genuineness of his alleged revelation and the supposed soundness of his arguments, The revelation may be spurious, the arguments unsound. ${ }^{67}$ If the arguments are valid, this only shows that the conclusion was validly derived from the premises. Should the conclusion of a valid argument be false - and the theist should entertain this possibility when confronted with the problem of evil - this shows that one or more of his premises are false. A valid argument with a false conclusion is a disproof of one or more of its premises. ${ }^{\text {s8 }}$

The consistent failure of apologists to produce a credible theodicy should be taken, according to the skeptic, as indicative of the fact that something is wrong with their initial assumptions or axioms. ${ }^{\text {(9) }}$ As Basil Mitchell rhetorically asked in his discussion of "Theology and Falsification", how long can the theist adopt the position that God has a morally sufficient reason for allowing evil, although he does not know which, without this position becoming just silly? ${ }^{70}$ It may be a sign of irrationality to consider one's assumptions "a settled matter, no subject to review or challenge". ${ }^{71}$

Aside from all the problems having to do with the question of knowing whether God exists, there are difficulties in Pike's

Antony Flew, God and Philosophy (New York, 1966), p. 59. Cf. also Madden and Hare, op. cit. p. 16.

107 Cf. Henze, p. 377.

is Cf. Flew, God and Philosophy; p. 59; Madden and Hare, p. 15; and also J. J. C. Smart, "The Existence of God", in New Essays.

6s Cf., for example, Madden and Hare.

70 In New Essays.

71 Pike, in "Hume on Evil". 
position which are caused by the special logic of the term "good" and by the fact that God is said to be perfectly good. Terence Penelhum, for instance, with the help of some elements of R.M. Hare's analysis of the logic of the term "good" in his The Language of Morals, ${ }^{72}$ has challenged Pike on the following grounds. According to Hare, "good" has an evaluative and a descriptive meaning, the former being primary. ${ }^{73}$ Although the evaluative meaning of "good" is stable - it has to do with its being a term of commendation-- " know the descriptive meaning is to know by what standards the speaker is judging". ${ }^{\text {.5 }}$ So, although we use the term "good" primarily as an epithet of commendation, there are criteria for applying such an epithet. Albeit these criteria may vary depending on the case and on the speaker, when we are talking of moral goodness these standards have to be the ones the speaker himself adopts, ${ }^{78}$ Penelhum goes on to argue. So, at least part of the logic of the term "good" is the requirement that whenever the term is applied some set of standards are being employed. This means that "the concept of moral goodness, when actually applied to a particular person by some particular person, ... still requires the attribution of a fairly specific set of choice patterns to the person to whom it is applied". ${ }^{77}$ Because of this, "there is something very odd about suggesting that although someone is morally good, I have no idea what he would do in a wide range of situations". ${ }^{78}$ Applying now all of this to God, whenever one calls him good, or perfectly good, one is not merely applying an epithet of commendation to God - although one is cer-

7.2 R. M. Hare, The Language of Morals ( ), Part II, especially ch. 9. Cf. Penelhum, Religion and Rationality, ch. 17. $118 \mathrm{ff}$.

${ }^{73}$ On his reasons for considering the evaluative meaning primary see pp.

7.4 C. Hare, Part II, chs. 6-8.

73 Hare, p. 146.

76 Penelhum, Religion and Rationality, pp. 248-249.

77 Ibid., p. 249.

7s Ibid., p. 249. Penelhum admits, however, that "it is quite possible for me to say that I do not know how he would handle a particularly knotty problem". 
tainly doing that- but one is also committing himself to what this being would be expected to do.

"In calling him good one is necessarily expressing the conviction that his behavior will satisfy a certain set of moral standards; and in this case as in others, it is vacuous to apply the concept of goodness without a fairly detailed idea of what these standards are. These standards are those that the speaker must apply to himself". ${ }^{72}$

So, whenever the theist calls God perfectly good, he is committed to saying that the reasons that God would have for allowing evil are compatible with his (the theist's) moral standards. This is enough in itself to limit very much, in most cases, the range of theodicies which the theist can accept. $^{80}$

Let us take an example used by Penelhum himself. According to most people's moral standards, moral values have preference over purely aesthetical ones. Say, then, someone suggests that the reason why God allows tuberculosis is that the sufferers of this disease "often acquire a charming pink flush and according to Puccini can often sing better than healthy people". ${ }^{81}$ if this had really been God's reason, most people, if they were consistent, would have to deny that God was perfectly good. So, this shows that one cannot go on and say that someone is perfectly good, even though one does not know what his reasons for allowing evil may have been. The theist cannot "remain confidently agnostic about the range of purposes for which God would allow evil". ${ }^{82}$ At the very least he would have to rule out a large number of possibilities. ${ }^{81}$

Should the theist be convinced by any of these arguments -and several of them are- he would have to come forth

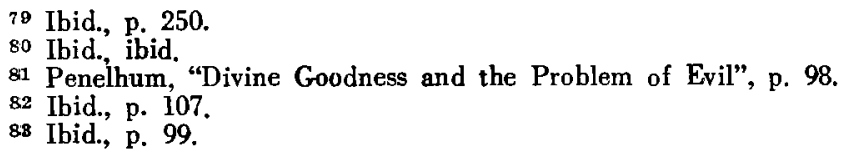


and try his hand at proposing full-fledged, specific theodicies. An examination of such specific proposals lies outside the scope of this paper, and has been admirably done by many people. ${ }^{54}$ The main purpose of this paper was to clarify some logical and semantical aspects of the problem of evil and to place some of the more recent discussions of the problem in some sort of synoptic perspective. And I am convinced that, although "clarity is not enough", it is certainly something - and something quite important.

84 Cf. Hick, Evil and the God of Love, who is excellent when he is criticizing somebody else's views and also very candid about his own views. Madden and Hare also criticize most theodicies which have been offered. 
¿Son los enunciados "existe el mal en el mundo" y "existe un Dios omnipotente, omnisciente y perfectamente bueno" lógicamente inconsistentes o incompatibles? Aun cuando muchos han contestado afirmativamente no es muy claro que esta posición pueda establecerse. Los que afirman que no hay contradicción entre los enunciados anteriores apelan a todo tipo de justificaciones para sostener su respuesta.

El propósito de este artículo es aclarar algunas consecuencias del problema y situar en una perspectiva sinóptica ciertas discusiones recientes sobre el tema. Si el autor tomara alguna posición, sería ésta: la equivocación semántica del problema evita el establecimiento de sus aspectos lógicos.

David Aiken sostiene que el problema del mal aparece cuando alguien está dispuesto a afirmar: (a) "hay un ser omnipotente y omnisciente que es perfectamente bueno y sólo él es Dios", y $(b)$ "hay algún mal en el universo finito creado por ese ser". Entre ambas proposiciones dice Aiken, se da una inconsistencia, pero como no es obvia hay que intentar mostrarla.

Por hipótesis, señala Aiken, un ser omnipotente y omnisciente puede hacer lo que quiera. Cualquier persona perfectamente buena, en tanto que pueda, hará el bien y prevendrá el mal. Si hay algún mal en el mundo debe concluirse, entonces, que no hay tal ser, pues una persona perfectamente buena prevendría el mal si pudiera. Entonces, o no hay tal ser o nada es malo. Pero como (por hipótesis únicamente) tal ser es Dios, nos vemos obligados a concluir que no hay Dios o, más aún, que no hay nada que sea malo.

El enunciado (a) contiene dos tesis: (i) la teológica, compuesta por tres partes: la metafísica, la moral y la religiosa, (ii) la ética. El componente metafísico señala que hay un ser que es omnipotente y omnisciente; el moral dice que hay un ser que es una persona perfectamente buena; el religioso apunta que sólo un ser que sea omnipotente, omnisapiente y perfectamente bueno es Dios. Esta distinción es importante porque permite ver con claridad que el teísta puede evadir el problema rechazando el componente metafísico o el moral. Si el teísta quiere rechazar el componente moral o el religioso, y seguir siendo teísta, debe antes rechazar la parte religiosa. Esto es, puede redefinir a Dios, pero esto no ofrece una solución al problema del mal tal como se planteo originalmente. Es curioso notar que los evasores del problema contestaron ya en sentido afir- 
mativo al problema original, pues, de otra manera, ¿para qué cambiar los términos del planteamiento?

Si aceptamos que "un ser omnipotente y omnisciente (de aquí en adelante 0 yO) puede hacer cualquier cosa que quiera" y que "cualquier persona perfectamente buena, en tanto que pueda, hará el bien y prevendrá el mal" es obvia la inconsistencia entre la tesis teológica y la ética. Las subpremisas anteriores explicitan parte del significado de los términos principales que intervienen en el argumento.

$\mathrm{El}$ asunto inmediato consiste en investigar si las mencionadas subpremisas son aceptables para el teísta y, si no lo son, ver por qué no lo son. Ningún teísta objetaría que "un ser OyO puede hacer cual. quier cosa que quiera" siempre y cuando no sea lógicamente imposible.

La segunda subpremisa es problemática. Nelson Pike afirma que es falso decir que una persona perfectamente buena (PB) prevendría el mal si pudiera. Ordinariamente no nos abstenemos de llamar bueno a alguien sólo porque permitió o causó algún mal, siempre y cuando haya tenido una "razón moralmente suficiente" para hacerlo. Este punto es "estrictamente semántico". Aunque no resulta claro qué se entiende aquí por "razón moralmente suficiente", es importante notar que Pike pretende, basándose en esta consideración, no sólo que no es cierto que "un ser $\mathrm{PB}$ prevendría el sufrimiento si pudiera", sino también que "si Dios es PB no se sigue que prevendría el sufrimiento si pudiera". La razón de esta afirmación surge de inmediato: "Dios podría fallar en la prevención del sufrimiento o causar él mismo algún sufrimiento y permanecer perfectamente bueno, sólo a condición de que haya una razón moralmente suficiente para su acción". El punto que sostiene Pike no es idéntico al anterior y tampoco se sigue de lo afirmado ahí. Esto se debe a que Dios, además de ser $\mathrm{PB}$, es también $\mathrm{OyO}$, y estos atributos morales parecen eliminar la posibilidad de que Dios tenga alguna razón moralmente suficiente (RMS). Así, los "atributos metafísicos" de Dios parecen impedir cualquier posibilidad de justificación del mal en el mundo. La maniobra que realiza Pike para salir avante es la siguiente: el escéptico es quien tiene que mostrar que ninguna RMS puede aplicarse a un ser OyO. Pero el escéptico debe mostrar no sólo que esto es verdadero, sino que es necesariamente verdadero. Esto, agrega Pike, nadie lo ha hecho y es difícil pensar cómo se pueda llevar a cabo.

E. O. C. Chaves no está de acuerdo con la maniobra de Pike, pues su argumento sólo muestra que hasta un ser $\mathrm{OyO}$ podría tener una RMS para permitir el mal (no que de hecho la tenga). Además, aun si tal argumento fallara, Pike siempre podría decir que dicha 
falla no prueba que la afirmación del escéptico sea necesariamente verdadera. El escéptico debe argumentar a favor de su afirmación.

Pike, mediante un extenso argumento, concluye que un ser $\mathrm{OyO}$ podría tener una razón para permitir que exista el mal y, por tanto, es imposible que el escéptico pueda mostrar que el enunciado "no hay razón moralmente suficiente aplicable a un ser $\mathrm{OyO}$ " es necesariamente verdadero.

La replica del escéptico es la siguiente: aun cuando las asunciones de Pike en su extenso argumento sean verdaderas, dicho argumento no muestra que el proyecto escéptico, para probar que no puede haber razón moralmente suficiente atribuible a un ser OyO, está condenado a fallar. Es más, el escéptico puede defenderse contra el argumento de Pike alegando que:

(1) Pike no demostró que podría haber una RMS aplicable a un ser $\mathrm{OyO}$.

(2) Pike mostró que podría haber una RMS atribuible a un ser O y y PB sólo con la ayuda de una noción muy extraña y atípica de bondad.

(3) Pike no mostró, ni con la ayuda de su extraña noción de bondad, por qué este ser $\mathrm{OyO}$ y $\mathrm{PB}$ debe decidirse a crear algo.

(4) Pike no mostró que este ser $\mathrm{OyO}$ y $\mathrm{PB}$ tuvo de hecho una RMS para permitir el mal -concedida su noción de bondad, sólo mostró que este ser podría haber tenido una razón para permitir la existencia del mal.

En los capítulos IV, V, vi y vi del artículo de O. E. C. Chaves se discuten los argumentos que el teísta podría esgrimir contra los puntos (1), (2), (3) y (4) del escéptico; también se analizan los posibles argumentos del escéptico contra el ataque teísta.

En el último capítulo de este trabajo se presenta el argumento de Pike, que enfoca el problema del mal en forma de una triada inconsistente:

(a) Hay mal en el mundo;

(b) Hay un Dios que es omnipotente, omnisciente y perfectamente bueno;

(c) No puede haber una razón moralmente suficiente para que Dios permita la existencia del mal en el mundo.

La relación entre estas tres proposiciones es tal que la afirmación de dos de ellas conduce a la negación de la restante. (a) es obviamente verdadera. El escéptico sostiene que $(c)$ es verdadera $y$, en consecuencia, $(b)$ debe ser falsa. La réplica de Pike es que el escép- 
tico no es capaz de mostrar que (c) es necesariamente verdadera y, por tanto, el teísta no está obligado a considerar $(c)$ como verdadera. Ahora bien, si el teísta está seguro, ya sea a través de un argumento a priori o a través de una revelación, de la verdad de $(b)$, entonces puede estar seguro de que $(c)$ es falsa, nada más sobre bases lógicas; en otras palabras, $(c)$ no sólo es, sino que debe ser falsa. En este caso el teísta puede estar seguro que de hecho Dios no sólo podría, sino que en verdad debe tener una RMS para permitir la existencia del mal. A esto el escéptico contestaría que la revelación puede ser espúrea y el argumento incorrecto y por tanto...

Además de los problemas que ocasiona el conocimiento de la existencia de Dios, varias dificultades salen al paso de Pike debido a la lógica particular del término "bueno", pues de Dios se dice que es perfectamente bueno.

(Resumen por Sebastión Lamoyi) 